\title{
Studies on Lysine Accumulation in the Broth Culture of Bacillus Species using Carbohydrates as Carbon Sources and Seed Meals as Nitrogen Sources
}

\author{
Okpalla J. ${ }^{1}$, Ekwealor I. A. ${ }^{2}$ \\ ${ }^{1}$ Senior Lecturer, ${ }^{2}$ Professor \\ 1Department of Microbiology, Chukwuemeka Odumegwo Ojukwu University, Uli, Anambra, Nigeria \\ 2Department of Microbiology and Brewing, Nnamdi Azikiwe University, Awka, Anambra, Nigeria
}

\begin{abstract}
Lysine production in the broth culture of Bacillus species using carbohydrates as carbon source and seed meals as nitrogen source was investigated. Different carbohydrate and proteins seeds were sourced from an open market in Awka Anambra State South Eastern Nigeria and prepared in the laboratory using standard procedures. The carbohydrates(carbon source) and seed meals(nitrogen source) were added into Erlenmeyer flasks containing the basal medium and inoculated with different cultures of Bacillus subtilis PR13, B. subtilis PR9 and B. pumilus SS16. Maize hydrolysate recorded the highest reducing sugar(5.2mg/ml), followed by sorghum $(4.8 \mathrm{mg} / \mathrm{ml})$ and the least was recorded by sweet potato $(2.1 \mathrm{mg} / \mathrm{ml})$.The best carbon source for maximum lysine yield by $B$. subtilis PR13 was millet, while for B. subtilis PR9 and B. pumilus SS16 it was sorghum respectively. Maximum lysine production by $B$. subtilis PR13 was stimulated at a millet concentration of $6 \%$, while enhanced lysine yield by $B$. subtilis PR9 and B. pumilus SS16 was observed at a sorghum concentration of $6 \%$. The best nitrogen source for enhanced lysine yield by $B$. subtilis PR13 and B. pumilus SS16 was soyabean meal respectively, while for B. subtilis PR9 the best was peanut meal. Optimum lysine yield by B. subtilis PR13 and B. pumilus SS16 was observed at soyabean concentrations of $4 \%$ and $2 \%$ respectively, while maximum lysine accumulation by $B$. subtilis PR9 was observed at $4 \%$. These findings indicate appreciable lysine production capability of Bacillus species when agricultural products are used as carbon and nitrogen sources.
\end{abstract}

Keywords: Lysine production, broth, Bacillus species, carbohydrates, seed meals

\section{INTRODUCTION}

Out of the twenty naturally occurring amino acids, L-lysine is one of the nine essential amino acids and commercially important amino acids. Lysine is an essential amino acid required mainly by children and growing animals. It cannot be synthesized biologically in the body (Shah et al., 2002), but may be added to food and feed materials to improve the protein quality (Stilling et al., 1971). Of that manufactured commercially, the largest amount $80 \%$ is produced by fermentation and $20 \%$ by chemical synthesis (Coello, et al., 2001). L-lysine is presently been used in the pharmaceutical, food, feed milling and cosmetics industries. Thus, the outlook for this amino acid is high because of its expanding market demand (Anastassiadis, 2007). The main difference between L-lysine produced for human consumption and that produced for animal feed is the level of purification of the final product. For human consumption, the form is typically that of a fine chemical used as part of a supplement or higher chemical application; In contrast, lysine for animal feed can be within the purity range of 35 to $80 \%$ (Anastassiadis, 2007). To determine the purity of the final product, downstream processing options including ion exchange chromatography and drying can be chosen.

L-lysine was discovered to be produced through fermentation by Corynebacterium glutamicum at Kyowa Hakko's plant in 1958 in Japan (Kelle et al., 2005). This method is preferred over all other methods because it employs low temperature, low pressure, low cost carbon sources and renders biological form of L-lysine as the final product (Nasab et al., 2007). Microorganisms that have been reported to produce L-lysine include Corynebacterium glutamicum (Nelofer et al., 2008), Bacillus megaterium
(Ekwealor and Obeta, 2005), Brevibacterium linens, Streptomyces Albulus IFO (Shih et al., 2006), Brevibacterium flavum, M. methylophilis (Ishikawa et al., 2008), B. lactofermentum (Tosaka et al., 1979), B. subtilis and Bacillus laterosporus (Umerie et al., 2000). Among these, C. glutamicum has been most widely exploited industrially for L-lysine production (Pfefferle et al., 2003). There are other different ways of L-lysine production which include chemical synthesis, enzymatic method, extraction from protein hydrolysate, recombinant DNA technology and protoplast fusion (Anastassiadis, 2007; Nelofer et al., 2008).

Agro-industrial by - products are being used as nitrogen and carbon source in lysine production(Ekwealor and Ebele , 2003).Sugar cane molasses is a cheap carbon source, containing sucrose, glucose and fructose at a total carbohydrate content of 50 to $60 \%$ (Reed, 1982). Glucose, fructose and sucrose are important carbon sources that have a pronounced effect on kinetics and stoichiometry of lysine production by C. glutamicum (Kiefer et al.,2002). It provides a source of fermentable sugars as well as some elemental nutrients, which plays key role in the fermentation process.

Nutritional and physical parameters affect the growth and product yield of organism (Wang et al., 1991; Coello et al., 1992). Since each bacterium has definite range of culture conditions for better growth and for high production of Llysine, therefore it is essential to investigate the effects of cultural conditions on bacterial growth and product yield. Product yield of organism is also strongly affected by the rate of sugar utilization or growth rate of a strain. 
The aim of the research was to study the influence of different carbohydrates and seed meals on lysine production.

\section{MATERIALS AND METHODS Collection of Samples}

Different carbohydrate samples such as cassava (Mannihot utilissima), yam (Dioscorea rotundata), millet (Bajra pennisetum americanum), sweet potato (Ipomea batatas), sorghum (Sorghum bicolor), maize (Zea mays) and rice (Oryza sativa) were purchased at the local market in Awka, Anambra State.

\section{Preparation of carbon sources}

They were prepared into starches in the laboratory according to standard procedures as described by Odibo (1987). Starch substrates were prepared from tubers (cassava, yam, sweet potato) and grains (rice, corn sorghum, millet). The tubers were cleaned to remove soil particles, peeled and washed (thrice) in clean water. They were cut into small pieces before being homogenized with water in a blender. Grains were soaked for $48 \mathrm{~h}$ to soften the seeds and then homogenized with water. The resulting mash or homogenate was collected in a white muslin cloth, squeezed to extract the starch (in suspension) into plastic bowl and allowed to settle. The supernatant was decanted and the sedimented starch dried at $50^{\circ} \mathrm{C}$ for $48 \mathrm{~h}$. The resultant flakes were ground into fine powder and used as native starch.

Enzyme hydrolysis of carbon sources for reducing sugar production

The enzyme hydrolysis was done following the method described by Umerie et al. (2000).A 500ml beaker containing $30 \mathrm{~g}$ of the starch in $100 \mathrm{ml}$ of water was heated for $15 \mathrm{~min}$ at $100^{\circ} \mathrm{C}$ to gelatinize the starch. The beaker was covered with an aluminium foil after adding $1.0 \mathrm{ml}$ of $\alpha$-amylase and heated again in a water bath for $10 \mathrm{~min}$ at $95^{\circ} \mathrm{C}$ to effect liquefaction. After cooling the liquefied starch to $60^{\circ} \mathrm{C}, 1.0 \mathrm{ml}$ amyloglucosidase was added before replacing the beaker in the bath at $60^{\circ} \mathrm{C}$ for $48 \mathrm{~h}$, for saccharification to take place.

\section{Preparation of nitrogen sources}

The protein seeds used cowpea (Vigna unguiculata), soyabeans (Glycine max), groundnuts(Arachis hypogea), bambara nuts (Vignia subterranean), were ground using a blender(Sonik, Japan). The seed meal $(20.0 \mathrm{~g})$ in $200 \mathrm{ml}$ solvent(chloroform-ethanol mixture 2:1) was defatted by the soxhlet extraction method. After extraction for $6 \mathrm{~h}$, the defatted meal was then oven-dried at $50^{\circ} \mathrm{C}$ for $20 \mathrm{~h}$.

\section{Lysine production in submerged culture Inoculum preparation}

Two loopfuls of the Bacillus species (24h) were grown in Erlenmeyer flasks containing $50 \mathrm{ml}$ of seed medium sterilized at $121^{\circ} \mathrm{C}$ for $15 \mathrm{~min}$. The seed medium consisted of peptone, $10.0 \mathrm{~g}$; yeast extract, $10.0 \mathrm{~g}$; NaCl, $5.0 \mathrm{~g}$; water, 1litre; $\mathrm{pH}$ adjusted to 7.2. The flasks were incubated for $24 \mathrm{~h}$ on a rotary shaker at $120 \mathrm{rpm}$ and $30^{\circ} \mathrm{C}$.

\section{Effect of carbon sources}

The effect of carbon sources (cassava, yam, sweet potato, millet, sorghum, maize, and rice) on growth and lysine production was examined. Various carbon sources(20g) were added into Erlenmeyer flasks $(100 \mathrm{ml})$ containing $20 \mathrm{ml}$ of the medium composed of $\mathrm{KH}_{2} \mathrm{PO}_{4}, 0.5 \mathrm{~g} ; \mathrm{K}_{2} \mathrm{HPO}_{4}, 0.5 \mathrm{~g}$; $\mathrm{MgSO}_{4} .7 \mathrm{H}_{2} \mathrm{O}, 0.001 \mathrm{~g} ; \mathrm{MnSO}_{4} . \mathrm{H}_{2} \mathrm{O}, 0.001 \mathrm{~g} ; \mathrm{FeSO}_{4} .7 \mathrm{H}_{2} \mathrm{O}$, 0.001g; $\mathrm{CaCO}_{3}, 50 \mathrm{~g} ;\left(\mathrm{NH}_{4}\right)_{2} \mathrm{SO}_{4}, 10 \mathrm{~g}$; Water, 1litre; $\mathrm{pH} 7.2$ for Bacillus subtilis PR13 and Bacillus pumilus SS16 and 25ml of a similar medium for Bacillus subtilis PR9. After sterilization the flasks were inoculated with $2 \mathrm{ml}$ of a $24 \mathrm{~h}$ seed inoculum of the Bacillus species and placed on a rotary shaker $(160 \mathrm{rpm})$ at $30^{\circ} \mathrm{C}$ for $72 \mathrm{~h}$. Thereafter, lysine production, bacterial growth and residual sugar were determined from the broth culture. The carbon source that gave the maximum lysine production was used for further studies.

\section{Effect of concentrations of carbon sources}

The effect of different concentrations (20-100g/l) of millet for $B$. subtilis PR13 and sorghum for B. subtilis PR9 and $B$. pumilus SS16 on growth and lysine production was determined. The fermentation process was carried out as previously described, and residual sugar, bacterial growth and lysine production determined after $72 \mathrm{~h}$.

\section{Effect of nitrogen sources}

Various nitrogen sources: peanut meal, bambara nut meal, soyabean meal, cowpea meal and their defatted seed meals were investigated for their effects on growth and lysine production. Various nitrogen sources $(10 \mathrm{~g})$ were added into Erlenmeyer flasks $(100 \mathrm{ml})$ containing $20 \mathrm{ml}$ of the medium composed of $\mathrm{KH}_{2} \mathrm{PO}_{4}, 0.5 \mathrm{~g} ; \mathrm{K}_{2} \mathrm{HPO}_{4}, 0.5 \mathrm{~g} ; \mathrm{MgSO}_{4} .7 \mathrm{H}_{2} \mathrm{O}$, 0.001g; $\mathrm{MnSO}_{4} . \mathrm{H}_{2} \mathrm{O}, 0.001 \mathrm{~g} ; \mathrm{FeSO}_{4} .7 \mathrm{H}_{2} \mathrm{O}, 0.001 \mathrm{~g} ; \mathrm{CaCO}_{3}, 50 \mathrm{~g}$; Water, 1litre; $\mathrm{pH} 7.2$ for B. subtilis PR13 and B. pumilus SS16 and $25 \mathrm{ml}$ of a similar medium for B. subtilis PR9.The carbon sources of the fermentation medium were millet $60.0 \mathrm{~g}$ for $B$. subtilis PR13 and sorghum $60.0 \mathrm{~g}$ for both $B$. subtilis PR9 and B. pumilus SS16. After sterilization the flasks were inoculated with $2 \mathrm{ml}$ of a $24 \mathrm{~h}$ seed inoculum of the Bacillus species and placed on a rotary shaker $(160 \mathrm{rpm})$ at $30^{\circ} \mathrm{C}$ for $72 \mathrm{~h}$. Residual sugar, bacterial growth and lysine production were determined as previously described. The nitrogen source that gave the maximum lysine production was used for further studies.

\section{Effect of varying concentrations of nitrogen sources}

The effects of varying concentrations $(10-80 \mathrm{~g} / \mathrm{l})$ of soyabean meal on growth and lysine production by B. subtilis PR13, defatted peanut meal for B. subtilis PR9 and deffated soya bean meal for $B$. pumilus SS16 were investigated. Fermentation process was carried out as previously described, and residual sugar, bacterial growth and lysine production determined after $72 \mathrm{~h}$.

\section{Estimation of reducing sugar}

The reducing sugar content of the saccharified starch was determined by dinitrosalicyclic acid (DNS) method of Miller (1959). The DNS reagent was prepared by adding $1.0 \mathrm{~g}$ of dinitrosalicyclic acid to $20 \mathrm{ml}$ of $2 \mathrm{M} \mathrm{NaOH}$ and $30 \mathrm{ml}$ of distilled water. Potassium sodium tatarate $(30 \mathrm{~g})$ was added and the volume of the mixture was increased to $100 \mathrm{ml}$ by the addition of distilled water. Reducing sugar was estimated by adding $1 \mathrm{ml}$ of DNS to $1 \mathrm{ml}$ of the hydrolyzed starch. The mixture was heated in a water bath at $100^{\circ} \mathrm{C}$ for $10 \mathrm{~min}$ and allowed to cool. The volume of the mixture was thereafter increased to $12 \mathrm{ml}$ with distilled water. After allowing the reaction mixture to stand for $15 \mathrm{~min}$ at room temperature, the optical density was measured at $540 \mathrm{~nm}$ in a spectrophotometer against a blank prepared by substituting the hydrolyzed sample with water. The reducing sugar content was subsequently determined by making reference to a standard curve of known glucose concentrations. 


\section{Quantitative determination of lysine}

Lysine in the broth culture was determined by acidic ninhydrin method of Chinard(1952).

\section{Determination of growth of bacterial isolates}

The growth of the bacterial isolates was determined turbidimetrically from the culture broth in Jenway (6405uv/vis) spectrophotometer at $660 \mathrm{~nm}$

\section{RESULTS}

Enzyme hydrolysis of carbon sources for reducing sugar production

The results of enzyme hydrolysis of carbon sources for reducing sugar production are shown in Fig 1. Maize, sorghum and millet recorded $5.2 \mathrm{mg} / \mathrm{ml}, 4.8 \mathrm{mg} / \mathrm{ml}$ and 4.4 $\mathrm{mg} / \mathrm{ml}$ of reducing sugars respectively. Others were yam starch $(3.9 \mathrm{mg} / \mathrm{ml})$, rice starch $(2.8 \mathrm{mg} / \mathrm{ml})$, cassava starch $(2.5 \mathrm{mg} / \mathrm{ml})$ and sweet potato starch $(2.1 \mathrm{mg} / \mathrm{ml})$.

\section{Effect of carbon sources}

The results of effect of carbon sources on growth and lysine production by B. subtilis PR13, B. subtilis PR 9 and B. pumilus SS16 are presented in Figs 2-4. The best carbon source for maximum lysine yield by $B$. subtilis PR13 was millet(Fig 2), while for B. subtilis PR9 and B. pumilus SS16 it was sorghum(Fig 3 and 4). B. subtilis PR13 produced the highest lysine yield of $1.71 \mathrm{mg} / \mathrm{ml}$ and the residual sugar was $0.47 \mathrm{mg} / \mathrm{ml}$.
Effect of varying concentrations of carbon sources

The results of the effect of varying concentrations of carbon sources on growth and lysine production by B. subtilis PR13, B. subtilis PR 9 and B. pumilus SS16 are shown in Fig 1113.The results show that maximum growth and lysine yields were observed in B. subtilis PR9 and B. pumilus SS16 when $60 \mathrm{~g} / \mathrm{l}$ sorghum was utilized (Fig 6 and 7), while B. subtilis PR13 accumulated the highest yield when $60 \mathrm{~g} / \mathrm{l}$ millet was utilized (Fig 5). The highest lysine yield of $2.08 \mathrm{mg} / \mathrm{ml}$ was produced by B. subtilis PR13.

\section{Effect of nitrogen sources}

Figs 8-10 show the effect of nitrogen sources on growth and lysine production by B. subtilis PR13, B. subtilis PR 9 and $B$. pumilus SS16. The best nitrogen source for maximum lysine yield for B. subtilis PR 13 and B.pumilus SS16 was soyabean meal (Fig8 and fig 10), while for B. subtilis PR9 it was defatted peanut. $B$. subtilis $\mathrm{PR} 13$ produced the highest lysine yield of $2.21 \mathrm{mg} / \mathrm{ml}$ and the residual sugar was $0.42 \mathrm{mg} / \mathrm{ml}$.

\section{Effect of varying concentrations of nitrogen sources}

The results of the effect of varying concentrations of nitrogen sources on growth and lysine production by $B$. subtilis PR13, B. subtilis PR 9 and B. pumilus SS16 are presented in Figs 11-13.The results show that maximum growth and lysine yields were observed in B. subtilis PR13 and B. pumilus SS16 when $40 \mathrm{~g} / \mathrm{l}$ and $20 \mathrm{~g} / \mathrm{l}$ of soyabean were utilized respectively(Fig11 and 12), while B. subtilis PR9 accumulated the highest yield when $40 \mathrm{~g} / \mathrm{l}$ of defatted peanut was used(Fig 13).

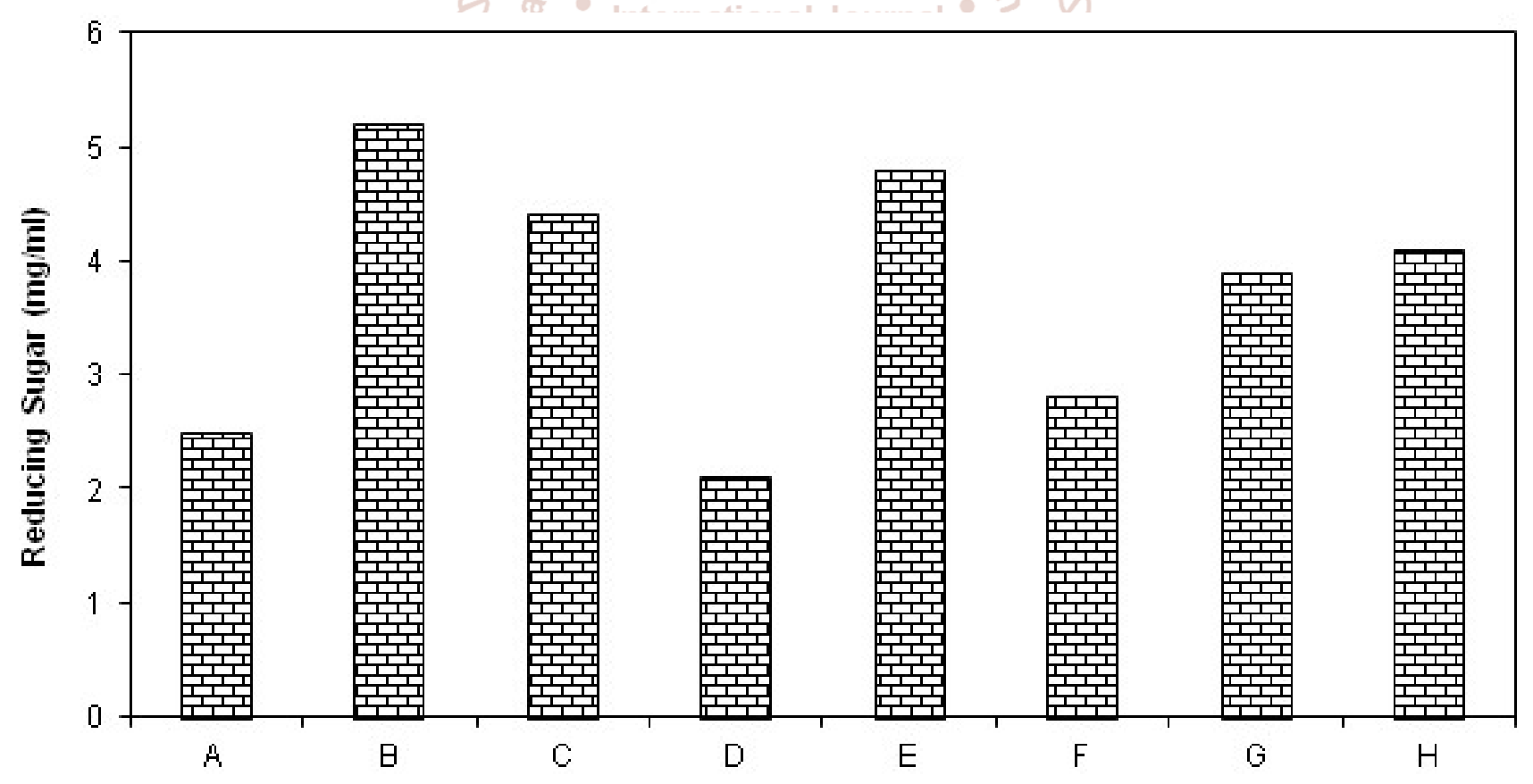

Carbon Source (g/)

Figure 1: Enzyme Hydrolysis of Carbon Sources for Reducing Sugar Production A, Cassava; B, Maize; C, Millet; D, Sweet Potato; E, Sorghum; F, Rice; G, Yam; H, Commercial Starch 


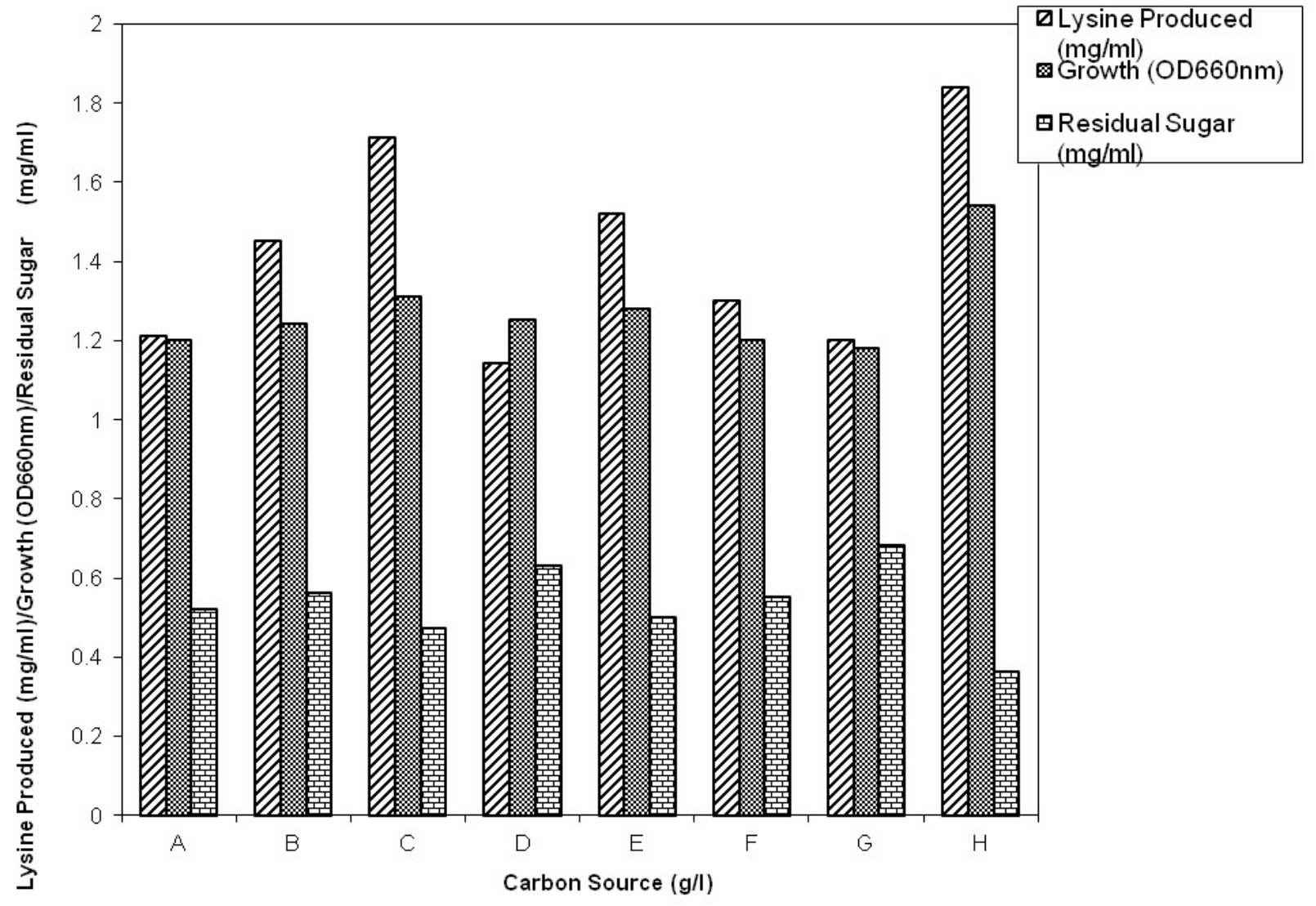

Figure 2: Effect of Carbon Sources on Lysine production by Bacillus subtilis PR13 A, Cassava; B, Maize; C, Millet; D, Sweet potato; E, Sorghum; F, Rice; G, Yam; H, glucose

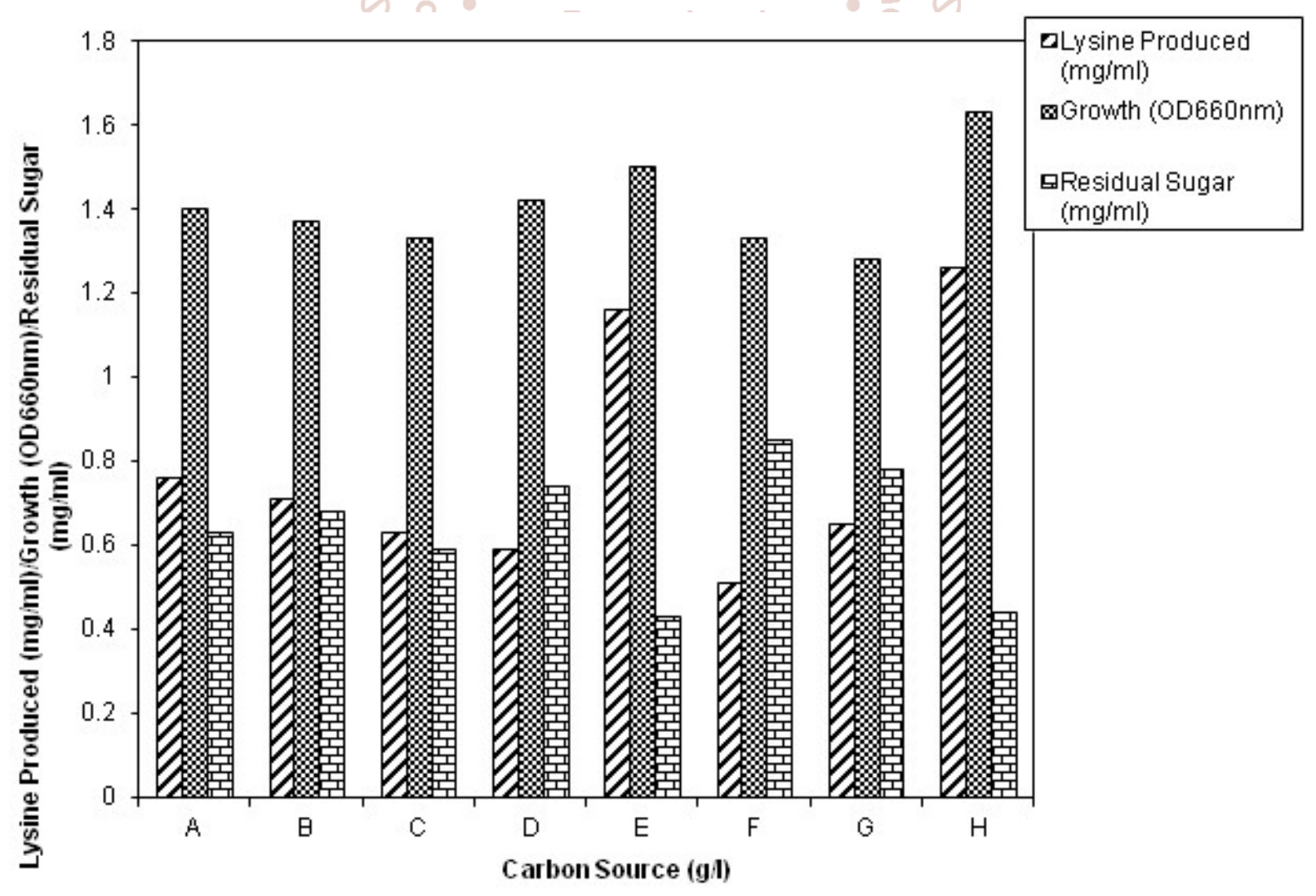

Figure 3: Effect of Carbon Sources on Lysine Production by Bacillus subtilis PR9: A, Cassava; B, Maize; C, Millet; D, Sweet Potato; E, Sorghum;

F, Rice; G, Yam; H, glucose 


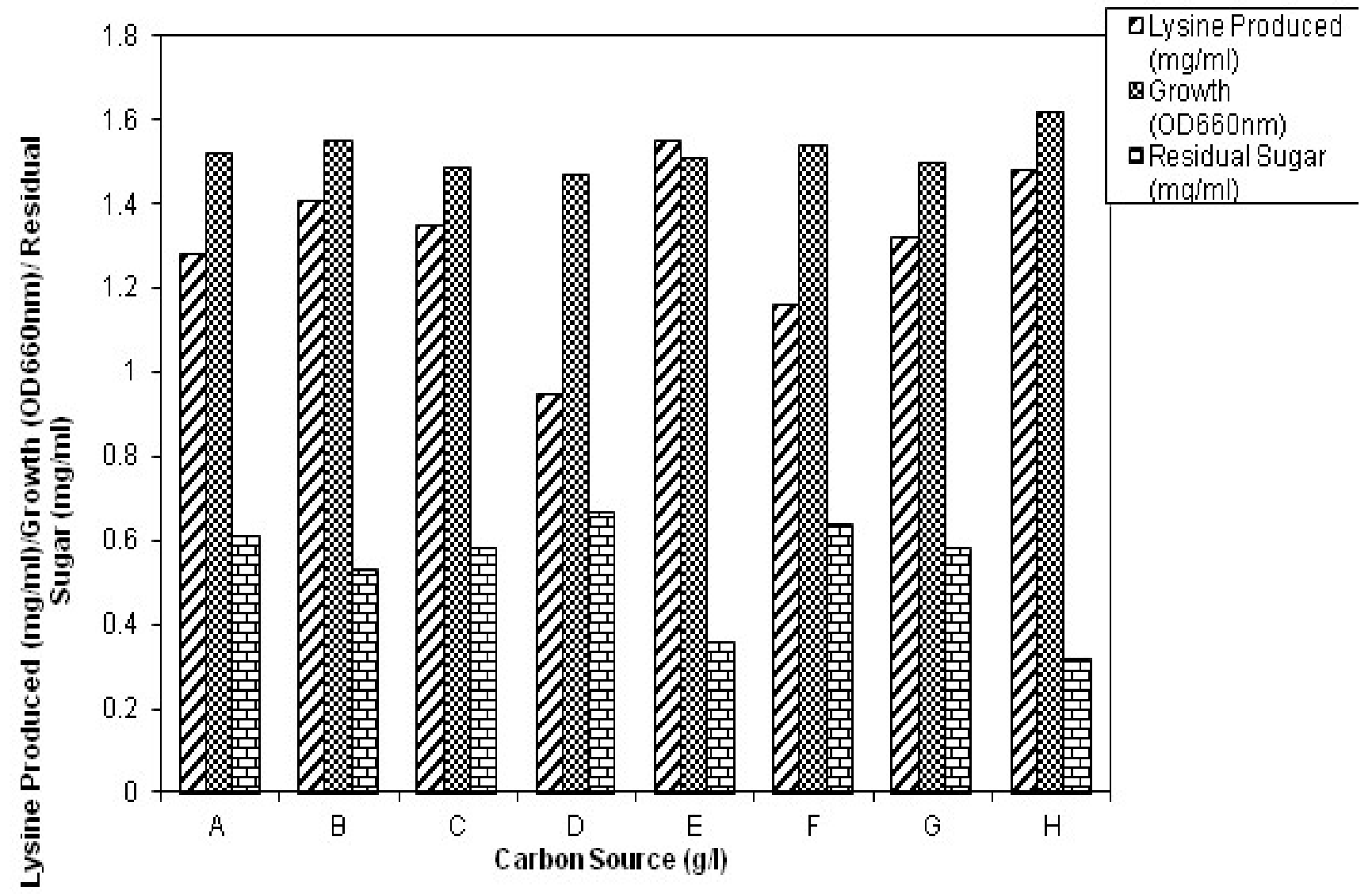

Figure 4: Effect of Carbon Sources on Lysine Production by Bacillus pumilus SS16 A, Cassava; B, Maize; C, Millet; D, Sweet Potato; E, Sorghum; F, Rice; G, Yam; H, glucose

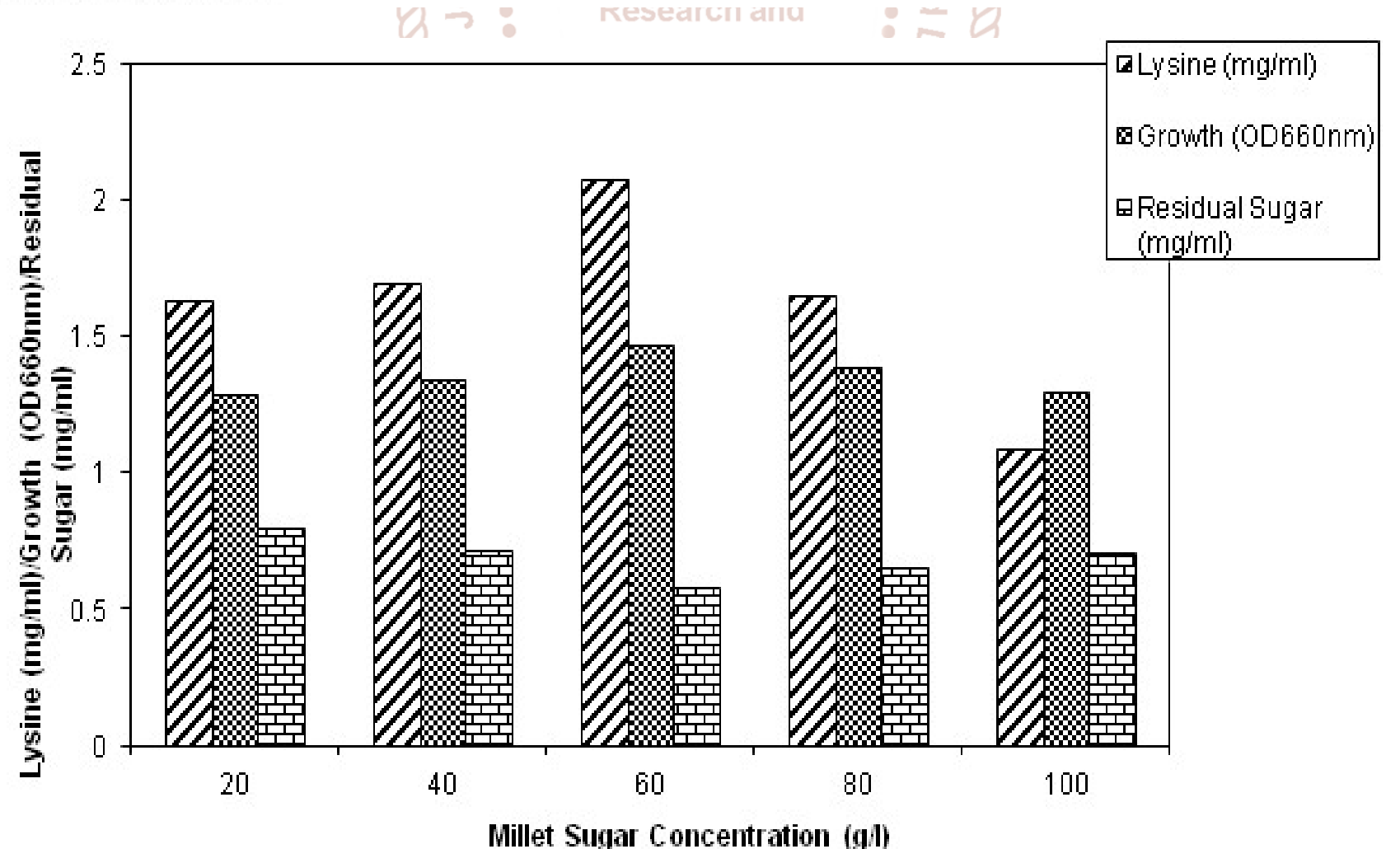

Figure 5: Effect of Varying Millet Sugar Concentrations on Lysine Production by Bacillus subtilis PR13 
International Journal of Trend in Scientific Research and Development (IJTSRD) @ www.ijtsrd.com eISSN: 2456-6470

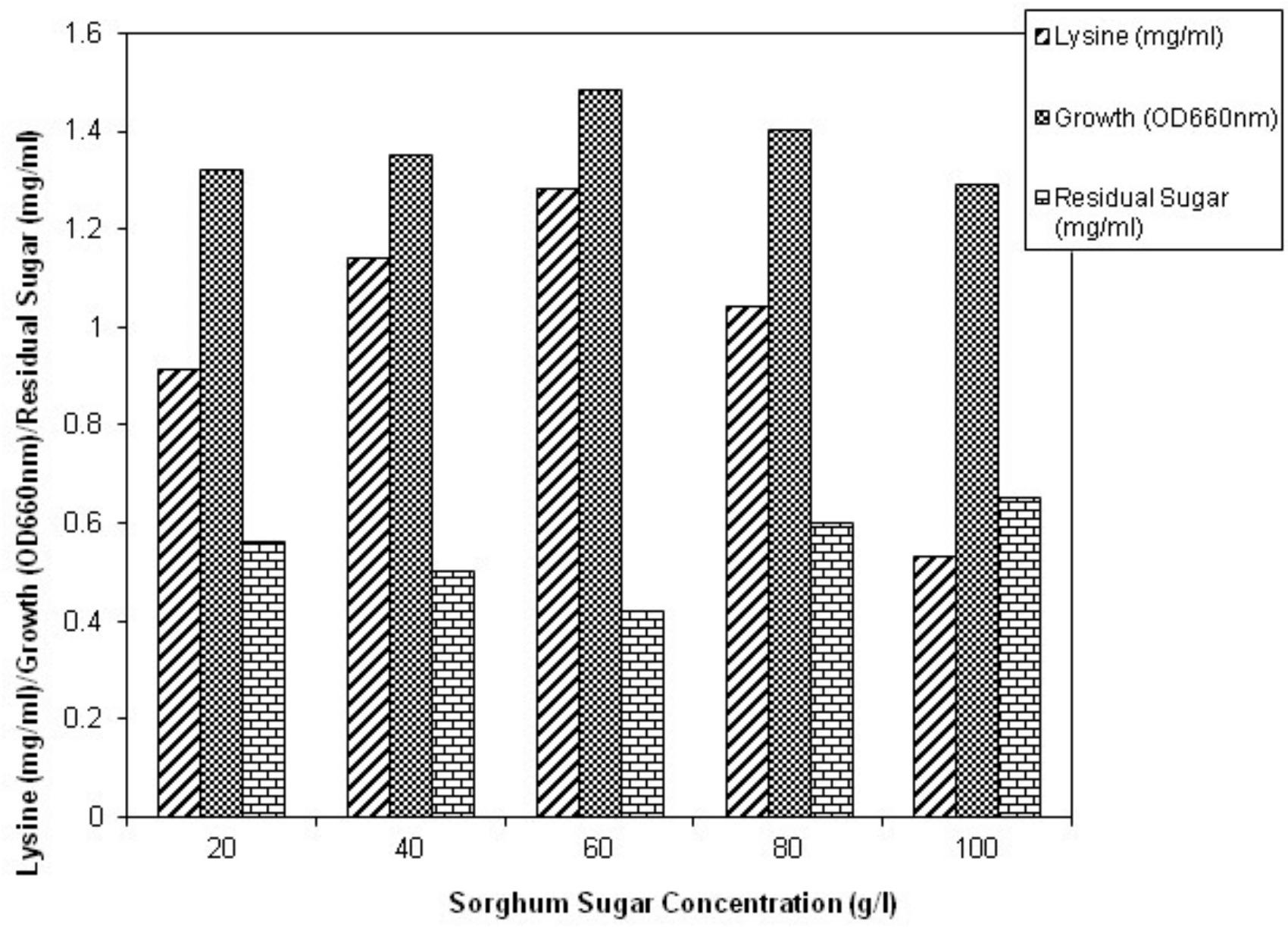

Figure 6: Effect of Varying Sorghum Sugar Concentrations on Lysine Production by Bacillus subtilis PR9

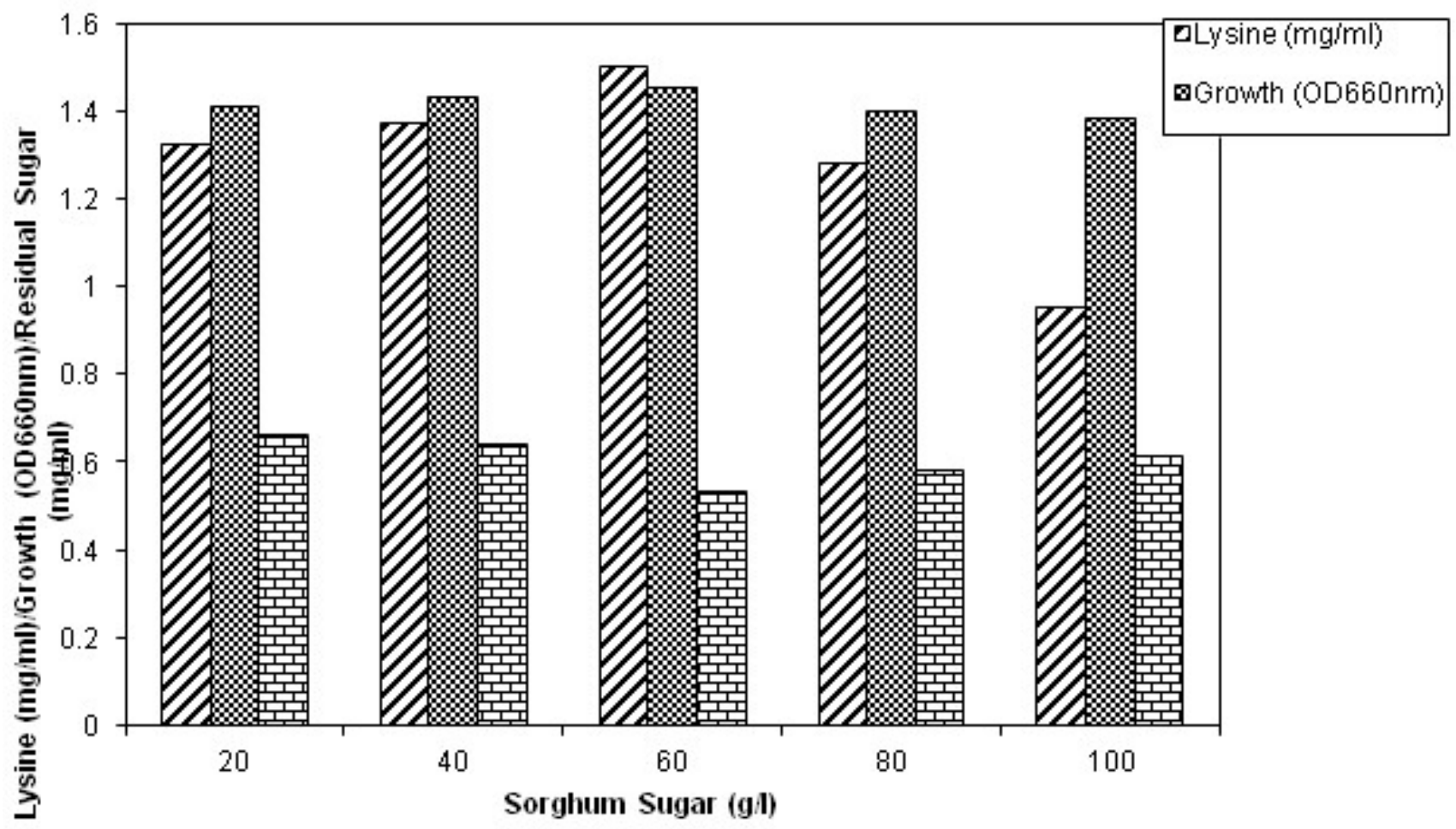

Figure 7: Effect of Varying Concentrations of Sorghum Sugar on Lysine Production by Bacillus pumilus SS16 

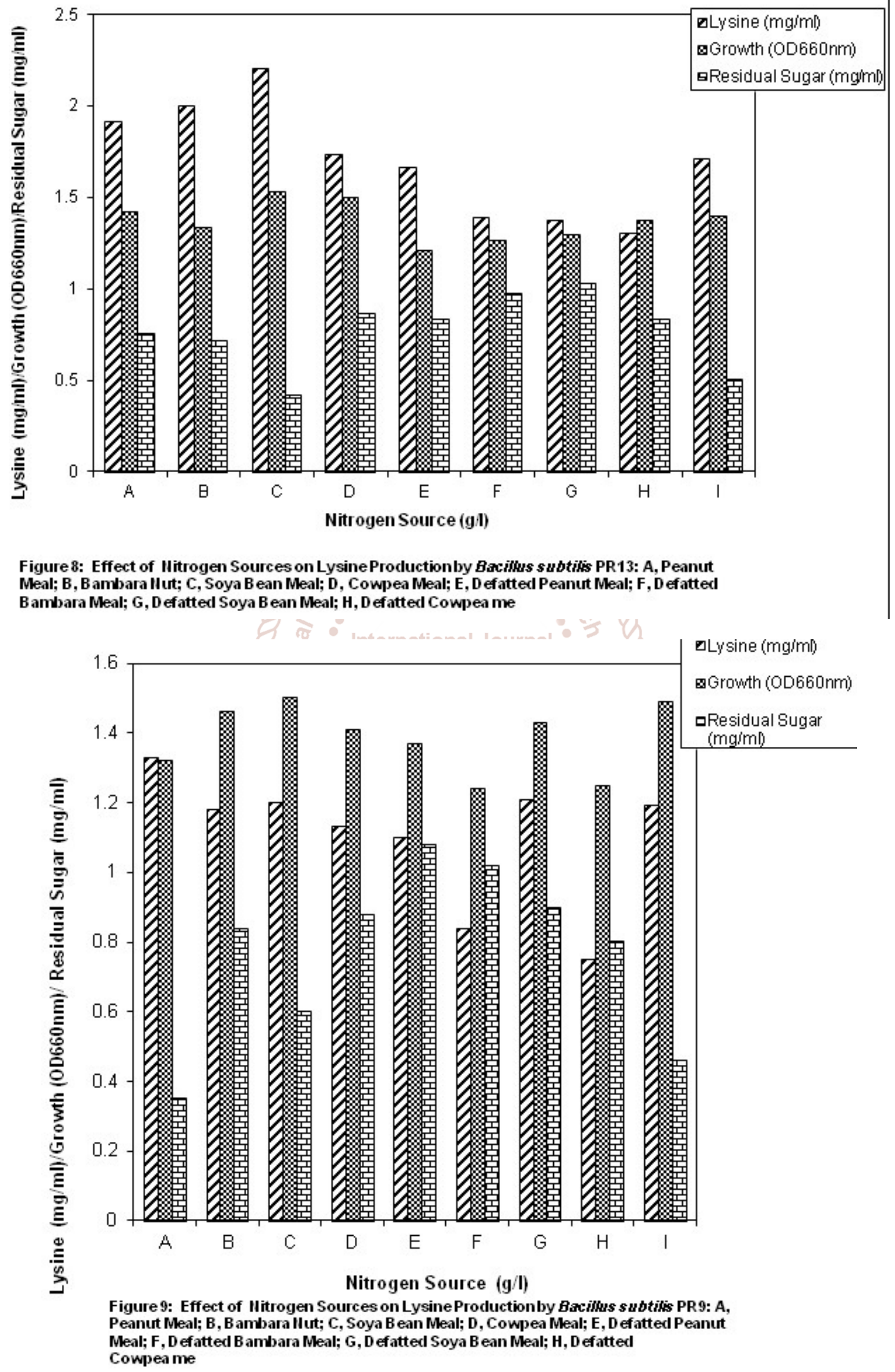
International Journal of Trend in Scientific Research and Development (IJTSRD) @ www.ijtsrd.com eISSN: 2456-6470

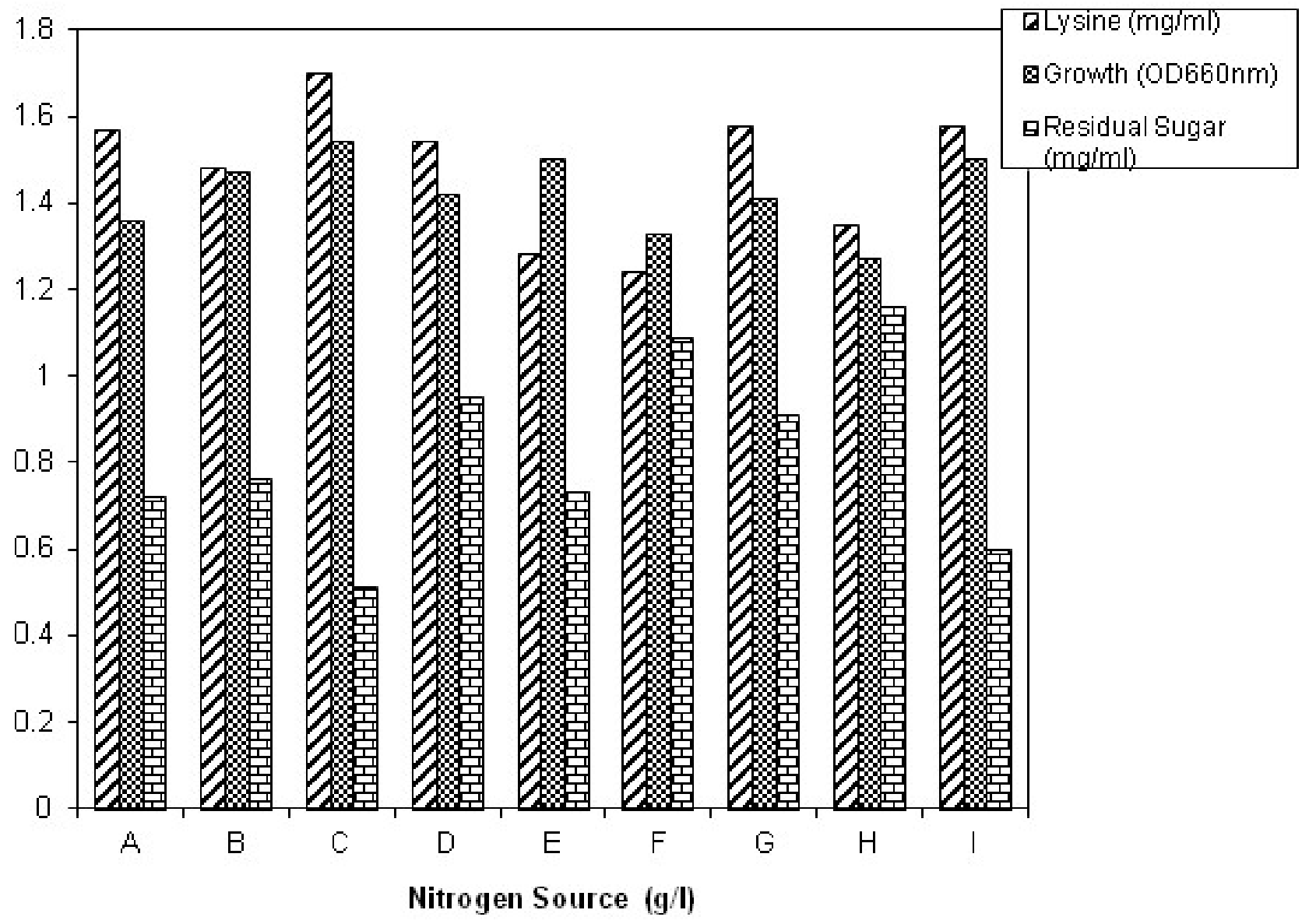

Figure 10: Effect of IItrogen Sources on Lysine Productionby Bicills pumilus SS16: A, Peanut Meal; B, B ambara IIut; C, Soya B ean Meal; D, Cowpea Meal;

E, D efatted Peanut Meal; F, D efatted B ambara Meal; G, D efatted Soya B ean Meal; H, Cowpea meal; I, A

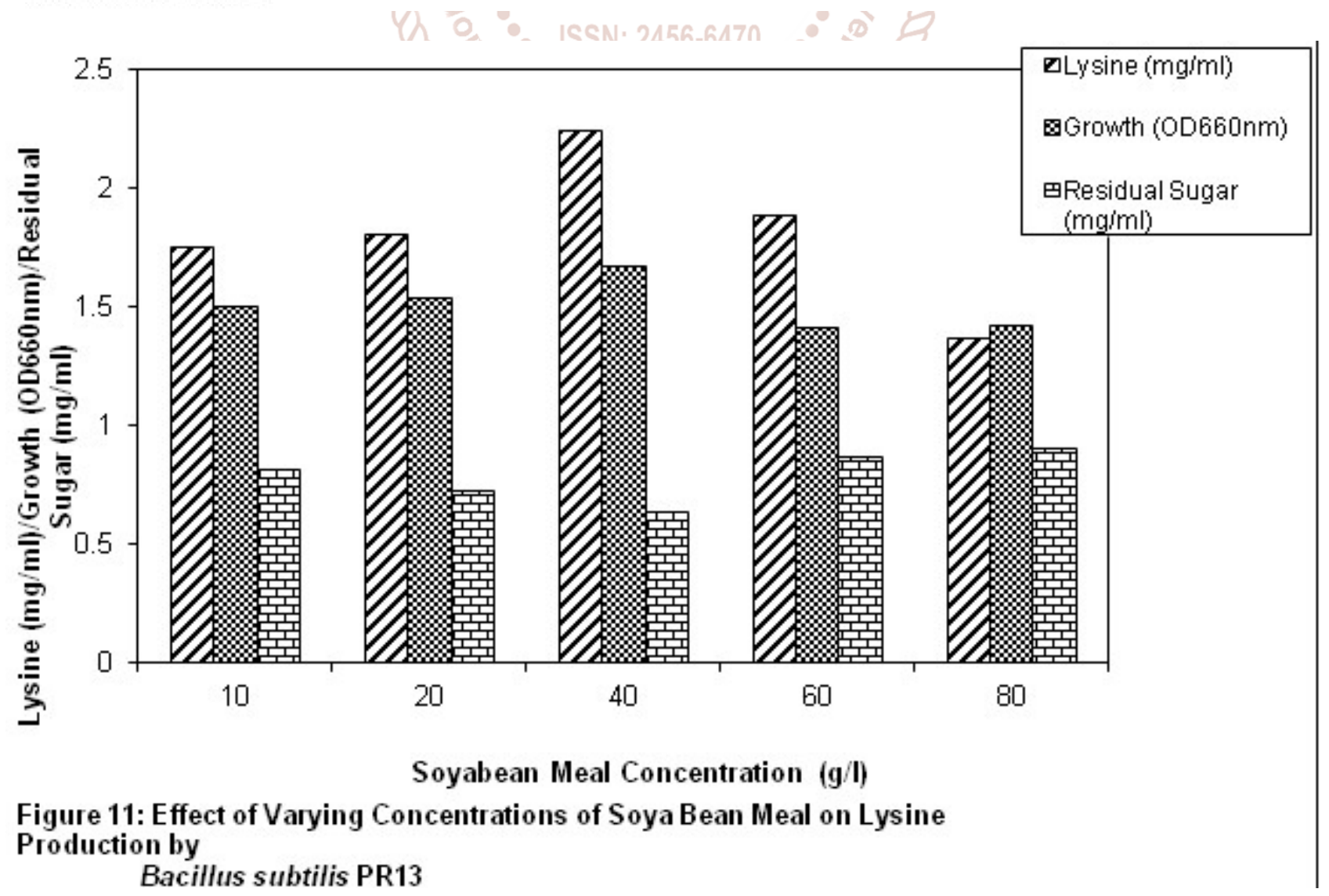




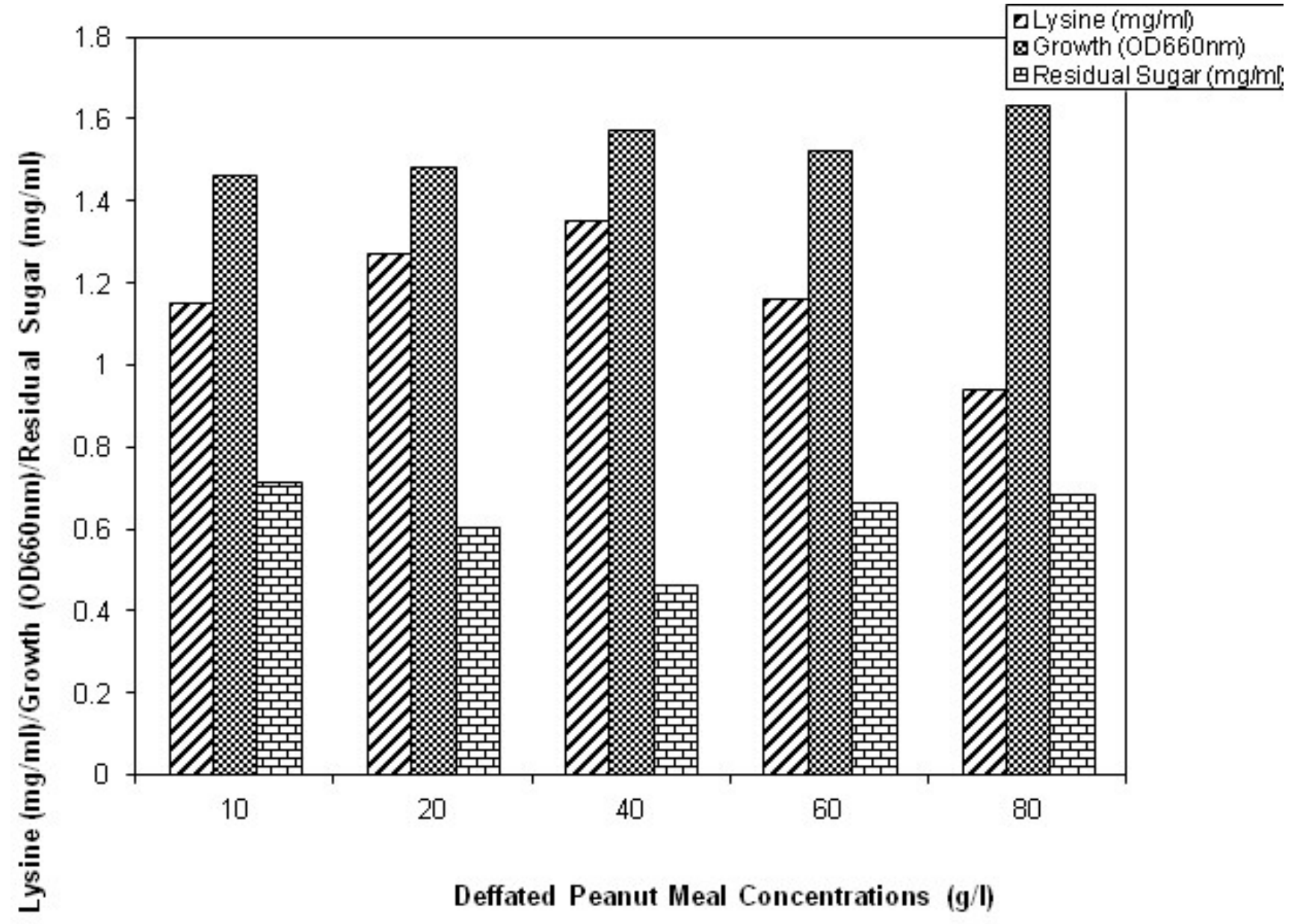

Figure 12: Effect of Varying Concentrations of Defatted Peanut Meal on Lysine Production by Bacillus subtilis PR9

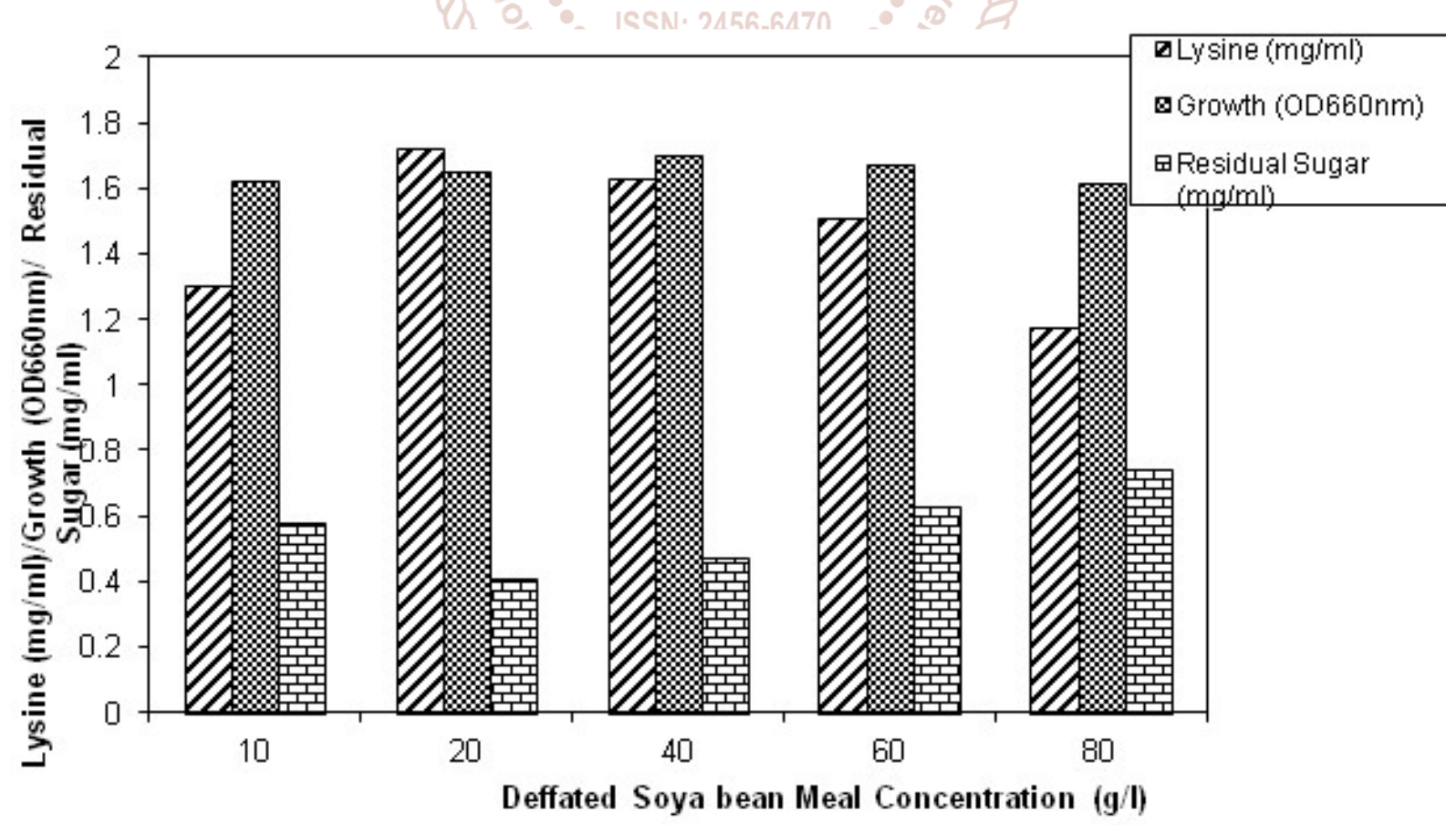

Figure 13: Effect of Varying Concentrations of Deffated Soya bean Meal on Lysine Production by Bacillus pumilus SS16 


\section{DISCUSSION}

The study showed the susceptibility of the different starch sources to enzyme hydrolysis with varying reducing sugar production. Maize starch recorded the highest reducing sugar yield as compared with other starches. This is consistent with the report of Omemu et al. (2005) that maize starch had the highest reducing sugar yield as compared with other starches. The susceptibility of starch granules to digestion by amylase is dependent on starch source and length of amylase treatment (Okolo et al., 1995; Achi and Njoku-Obi 1992; Omemu et al., 2005). Sweet potato was hydrolysed in the study producing $2.1 \mathrm{mg} / \mathrm{ml}$ of reducing sugar and this was contrary to the reports of Taniguich et al. (1982) and Okolo et al. (1995), that sweet potato starch was not easily hydrolyzed. Omemu et al. (2005) suggested that the ability of the crude amylase of A. niger AMO7 to hydrolyze the root starches especially cassava starch presented a remarkable property since these roots starches are abundantly available in the tropics. According to Anthony et al. (1996) and Oluwole et al. (1999) over 30 million tones of cassava are lost yearly since it is perishable after harvesting. Conversion of raw cassava by this enzyme means that some of the cassava could be used as raw materials by the starch industry for value added products. This will reduce wastage and improve economic gain.

The hydrolysates of millet for B.subtilis PR13 and sorghum for B.subtilis PR9and B.pumilus SS16 stimulated the highest growth and lysine production. Similar finding has been reported by Umerie et al. (2000) who reported that millet produced the highest lysine yield by B. laterosporus. Other workers used different starch hydrolysate for amino acid production. Nampoothiri and Pandey, (1999) reported that strain of Brevibacterium sp DSM utilized cassava starch hydrolysate and accumulated $21 \mathrm{~g} / \mathrm{l}$ of L-glutamic acid. Kubota et al. (1970), used sweet potato starch hydrolysate and obtained $5.20 \mathrm{~g} / \mathrm{l}$ of L-lysine $\mathrm{HCl}$ by threonine-valine auxotroph of Brevibacterium lactofermentum. Production strains of C. glutamicum and Brevibacterium species are able to grow and synthesize L-lysine in the fermentation medium with the paper hydrolyzate as the source of monosaccharides. The production of 20-24g of lysine per liter was achieved in media where hydrolysate was supplemented with saccharose that permited the sufficient growth with the simultaneous initiation of the production of L-lysine (Pelechova et al., 1983). Smekal et al., (1983) reported lysine production in the range $36-44 \mathrm{~g} / \mathrm{l}$ when carbon sources which included hydrolysates of cereal starch were utilized by Corynebacterium glutamicum. Pharm et al.(1989), reported that lysine yield increased 1.5 fold to $16.9 \mathrm{~g} / \mathrm{l}$ when sugar cane juice enriched with coconut water was used by a homoserine auxotroph, derived from Corynebacterium glutamicum ATTCC 13032.

Results from the study showed that sweet potato hydrolysate stimulated the lowest lysine production in B.subtilis PR13 and B.pumilus SS16 and this was similar to the findings of Shah and Hameed (2004).They recorded low lysine production (15 to $28 \mathrm{~g} / \mathrm{l}$ ) in a medium containing starch hydrolysate using Corynebacterium glutamicum. They suggested that starch hydrolysates have relatively low content of monosaccharide, therefore the quantity of lysine that would be produced will be reduced compared to the use of glucose. Javed et al.(2011), observed that bacterial cells grown on $20 \mathrm{~g} / \mathrm{l}$ of corn steep liquor had higher quantities of lysine as compared to sucrose $(3.57 \mathrm{~g} / \mathrm{l})$ and acetate(14.82g/l) because corn steep liquor is a rich source of glucose and other growth enhancing products that can accelerate growth and product yield of microorganisms. Liu (1986) studied optimization conditions of different parameters for lysine production with cane molasses by Brevibacterium species and achieved high yield after optimization.The results of the study showed that $6 \%$ millet for Bacillus subtilis PR13 and 6\% sorghum for Bacillus subtilis PR9 and Bacillus pumilus SS16 stimulated the highest amount of lysine. The finding is not in agreement with the report of other workers. Wang et al.(1991) reported that 9 and $16 \%$ initial sugar for molasses and sugar media respectively were optimum for lysine production. In a separate study conducted by Roy and Chatterjee (1989) they observed that $8 \%$ of glucose concentration produced the highest amount of glutamic acid respectively. Nampoothiri and Pandey (1995), reported that maximum yield of glutamic acid $(6.86 \mathrm{mg} / \mathrm{ml})$ was obtained when $2 \%$ glucose medium was fermented for $48 \mathrm{~h}$ by a Brevibacterium species. Also, Ekwealor and Obeta (2005) in their study observed that B. megaterium SP14 recorded the highest amount of lysine when $8.0 \%(\mathrm{w} / \mathrm{v})$ glucose was used as source of carbon. Hadj-Sassi et al.(1988), reported the influence of initial concentration of glucose from 80 to $233 \mathrm{~g} / \mathrm{l}$ on the production of L-lysine by Corynebacterium species in batch and feed batch culture. The maximum conversion rate in Llysine was obtained at $165 \mathrm{~g} / \mathrm{l}$ and the best specific production rate of L-lysine was observed at $65 \mathrm{~g} / \mathrm{l}$ of glu cose. Pfefferle et al.(2003), reported that lysine was exclusively produced in a bioprocess employing Corynebacterium glutamicum which generates a large amount of L-lysine from cane sugar and corn starch. Decrease in lysine production at higher carbon source (millet and sorghum) concentrations might be due to feed back inhibition of higher levels of carbon source that reverses the glycolytic pathway and inhibits the utilization of glucose (Ikeda, 2003). Pham et al. (1992), used sugarcane juice, molasses, banana, cassava and coconut water as carbon sources for methionine production. Glucose is the most widely used carbon source (Kase and Nakayama, 1974; Chattopadhyay et al., 1995 a, b), but Banik and Majumdar (1974) reported maltose as the best carbon source for the production of methionine.

The stimulation of lysine production by soyabean meal in B.subtilisPR13 and B.pumilus SS16 is similar to the report of Adnan et al.(2011).They studied the selection of subtrates for L-lysine production by Brevibacterium linens DSN 20158 and observed maximum L-lysine production $(2.213 \mathrm{~g} / \mathrm{kg})$ with soyabean meal. There was no general defined medium for lysine production by different microbial strains(Pandey et al.,(2000).Every microorganism has its own characteristic physico-chemical and nutritional requirements for L-lysine production. In view of the economical use of the L-lysine, cheap medium formulation was kept in mind. Therefore cheap solid substrate i.e. Soybean meal was used for the maximum production of L-lysine as reported by Ekwealor and Orafu (2003), because it is a good source of proteinaceous nitrogen and other nutritious substances essential for bacterial growth. Umerie et al.(2000) studied the effects of various nitrogen sources and was able to observe that defatted soyabean meal stimulated the highest amount of lysine. Smekel et al.(1982), studied the production of L-lysine with the strain of Brevibacterium flavum and Corynebacterium glutamicum, using saccharose technology and non standard nitrogen sources such as hydrolysates of extracted rap, flax and cotton plant crush and hydrolysates 
of fodder yeast. Using these nitrogen sources the production in a range from 36 to $45 \mathrm{~g}$ L-lysine per liter was achieved. Again Smekel et al. (1984), studied the biosynthesis of Llysine in Corynebacterium glutamicum and Brevibacterium flavum using media with a hydrolysate of phosphorcarpus flour, they observed a lysine yield of 44 and $30 \mathrm{~g} / \mathrm{l}$ respectively.

It is concluded from the present studies that the production of L-lysine from Bacillus species can be substantially enhanced by optimizing the culture medium. Carbon and nitrogen sources have also been found to have influential role in the amino acid production.

\section{REFERENCES}

[1] Achi, O.K. and Njoku-Obi, A.N.U. (1992). Production of a raw starch saccharifying amylase by Bacillus alvei grown on different agricultural substrates. World Journal of Microbiology and Biotechnology, 8:206-207.

[2] Adnan, A., Lam, R., Chen, H., Lee, J., Schaffer, D.J., Barnard, A.S., Schatz, G.C., Ho, D. and Liu, W.K. (2011). Homostatic stimulation and measurement of $\mathrm{pH}$. Journal of Applied Pharmaceutical Science, 1(6): 29-39.

[3] Anastassiadis, S. (2007). L-Lysine fermentation. Recent Patents on Biotechnology, 1: 11-24.

[4] Anthony, O.E., Yusuf, E. and Murray, M. (1996). Culture of Saccharomyces cerevisiae on hydrolysed waste cassava starch for production of baking quality yeast. Enzyme in Microbial Technology, 18(7): 519-525.

[5] Banik, A.K. and Mujumdar, S.K. (1974). Studies on methionine fermentation: part I. Selection of mutant of Micrococcus glutamicus and optimum conditions for methionine production. ndia Journal of Experimental Biology, 12: 363-5.

[6] Chattopadhyay, M.K., Ghosh, A.K., Sengupta, S. and Sengupta, D. (1995a). Threonine analogue resistant mutants of Escherichia coli K- 12. Biotechnology Letters, 17: 567-70.

[7] Chattopadhyay, M.K. Sengupta, D and Sengupta, S. (1995b). Fermentative production of ethionine by 5-bromouracil resistant mutants of Eschericha coli K12. Medical Science Research, 23: 775.

[8] Chinard, F.P. (1952). Photometric estimation of proline and ornithine. Journal of Biological Chemistry, 199: 9195.

[9] Coello, N., Bianchi, D.,

[10] Coello,N., Pan, J.G. and Lebault, J.M.(1992). Physiological aspect of L-lysine production. Effect of nutritional limitations on a producing strain of Corynebacterium glutamicum. Applied Microbiology and Biotechnology, 38:259-262

[11] Ekwealor, I.A. and Obeta, J.A.N. (2005). Studies on lysine production by Bacillus megaterium. African Journal of Biotechnology, 4(7): 633-638.

[12] Ekwealor, I. A and Ebele, O.A., (2003). Preliminary study of L-lysine production by Bacillus species using various agricultural by products. Nahrung, 47: 226227.
[13] Ekwealor, I.A. and Orafu, A.E. (2003). Preliminary study of L-lysine production by Bacillus species using various agricultural by-products. Nahrung/Food 47: 226-227

[14] Hadj-Sassi, A., Queric, M.P., Deschamps, A.M. and Lebeault, J.M. (1988). Optimization of L-lysine production by Corynebacterium species in fed-batch culures. Biotechnology Letters, 10:583-586.

[15] Hagino, H. S., Kobayashi, K., Arki and Nakayama,K. (1981). L-Lysine production by mutant of Bacillus licheniformis. Biotechnology letters, 3:425-430.

[16] Hallaert, J., Westgaver, E.M. and Vandamme, E.J.(1987).L- Lysine fermentation by aminoethyl cysteine resistant Corynebacterium glutamicum. Rijksuniv Gent, 52:1901 - 1906

[17] Hallaert, J., Westgaver, E.M. and Vandamme, E.J. (1981). L-lysine fermentation by aminoethyl cystein resistant Corynebacterium glutamicum. Rijksuniv Gent, 52: 19011906.

[18] Hamilton, B.K. and Jackson, D.A.(1985). Amino acid production: recent advances. In proceeding:Bio- Expo 85,Cahners Exposition Group, Stamford, Connecticut pp 295-304.

[19] Hamilton, B.K., Hsiao, H.Y., Swann, W.E., Anderson, D.M. and Delente, J.J. (1985). Manufacture of L-amino acids with bioreactors. Trends in Biotechnology, 3:64-68

[20] Hanel, F., Hiller, M. and Grafe, U. (1981). Effect of oxygen limitation on cellular L-lysine pool and lipid spectrum of Corynebacterium glutamicum. Biotechnology letters, 3: 461-464.

[21] Harol, F.M. (1986). A study of bioenergetic. Freeman and Co. New York.

[22] Hatem, S.M.A. (2006). Gas chromatographic determination of Amino Acid Enantiomers in tobacco and bottled wines. University of Giessen. http://geb.uni.giessen.de/geb/volltext/2006/3038/in dex.thml

[23] Heinrich, R. and Rapoport, T.A. (1974). Linear steady state treatment of enzymatic chains. Critique of the crossover neorem and a general procedure to identify interation sites with an effector. European Journal of Biochemistry, 42:97-105.

[24] Hermann, T. (2003). Industrial production of amino acids by Coryneform bacteria. Journal of Biotechnology, 104: $155-72$.

[25] Herrman, K.M. and Somerville, R.L. (1983). Amino acids biosynthesis and genetic regulation. Adison-Wesley publishing company Massachusetts, pp 147-244.

[26] Hilliger, M. and Prauser, H. (1989). L-Lysine formation in the Nocardioform Taxon. Oerskovia. Folia Microbiology 34: 427-428.

[27] Hilliger, M., Haenel, F. and Men, J. (1984). Influence of temperature on growth and lysine fermentation in Corynebacterium glutamicum. Microbiology, 24:437-441

[28] Hirao, T., Nakan, T., Azuma, T. and Nakanishi,T. (1989). Process for producing L-lysine. European Patent 327945. 
International Journal of Trend in Scientific Research and Development (IJTSRD) @ www.ijtsrd.com eISSN: 2456-6470

[29] Hirose, Y., Sano, K. and Shibal, H. (1978). Amino acids. Annual Report of Fermentation Procedures, 2: 159-169.

[30] Hoare, D.S. and Work, E. (1957). The stereoisomers of $\alpha$ - $\boldsymbol{\varepsilon}$-diaminopimelic acid 2, their distribution in the bacterial order Actinomycetales and in certain Eubacteriales. Journal of Biochemistry, 65: 441.

[31] Hofler, A., Alt, H.C., Klasen, C.J., Friedrich, H., Hertz, U., Morl, L. and Schutte, R. (1997). Process for the preparation of an animal feed supplement based on fermentation broth. European patent application EP 809940

[32] Holt, G.H., Krieg, N.R., Sneath, P.H.A., Stanley, J.T. and Williams, S.T. (1994). Bergey's Manual of Determinative Bacteriology. 9th ed Willimans and Wilkins, Baltimore p787.

[33] Hopwood, D.A. (1970). Isolation of mutants. In: Norris J.R., Ribbons DW, Editors. Methods in Microbiology, Academic press; London p392-400

[34] How, E., Jansen, G.R. and Gillfillam, E.W.(1965). Improving the quality of proteins of edible cereals by amino acid supplementation. American Journal of Clinical Nutrition, 16:315-320

[35] Ikeda, M. (2003). Amino acid production processes. Advances in Biochemical Engineering and Biotechnology, 79: 1-35.

[36] Ishikawa, K., Toda-Murakoshi, Y., Ohnishi, F., Kondo, K., Osumi, T. and Asano, K. (2008). Medium composition suitable for L-lysine production by Methylophilus methylotropus in fed-batch cultivation. Journal of Bioscience and Bioengineering, 106 (6): 574-579.

[37] Javed, A., Jamil, A. and Rezaei-Zarchi, S. (2011). Optimization and hyper-expressed production of lysine through chemical mutagenesis of Brevibacterium flavum by N-nitroso-N-ethylurea. African Journal of Microbiology Research, 5(29): 5230-5238.

[38] Kase, H. and Nakayama, K. (1974). Production of oacetyl-L-homoserine by methionine analog resistant mutants and regulation of homoserine-otransacetylase in Corynebacterium glutamicum. Agricultural and Biological Chemistry, 38: 2021-30.

[39] Kelle, R., Hermann, T. and Bathe, B. (2005). L-Lysine production. In: Eggeling L, Bott M (eds) Handbook of Corynebacterium glutamicum. CRC press, Boca Raton, USA pp 465-488

[40] Kiefer, P., Heunzle, E. and Wittman, C. (2002). Influence of glucose fructose and sucrose as carbon sources on kinetics and stoichiometry of lysine production by Corynebacterium glutamicum. J. ind. Microbiol. Biotechnol., 28: 338-343.

[41] Kubota, K., Maeyashiki, I., Shiro,T., Noborn, K. S. and Kamagawa. K.(1970). Method of producing L-lysine. US Patent, No, 35: 270-285

[42] Liu, Y.T. (1986). Studies on the fermentation production of L-lysine. Optimization of culture condition for L-lysine fermentation with cane molasses. Report Taiwan and sugar Research Institute 114: 45-66.
[43] Miller, G.L. (1959). Use of dinitrosalicyclic acid reagent for detection of reducing sugar. Annals of Chemistry 31: 427-431

[44] Nampoothiri, K.M. and Pandey, A. (1999). Fermentation and recovering of L-glutamic acid from cassava starch hydrolysate by ion-exchange resin column. Reviews in Microbiology, Vol 30.

[45] Nampoothiri, K.M. and Pandey, A.(1995).Effect of different carbon sources on growth and glutamic acid fermentation by Brevibacterium species. Journal of Basic Microbiology, 35: 249-254.

[46] Nasab, M.M., S. Ansari and Z. Montazer. 2007. Fermentative production of lysine by Corynebacterium glutamicum from different carbon sources. Iran Agri. Res., 25(2): 99-106.

[47] Nelofer, R., Q. Syed and M. Nadeem. 2008. Statistical Optimization of Process Variables for L-lysine production by Corynebacterium glutamicum. Turk. J. Biochem., 33 (2): 50-57.

[48] Odibo, F.J.C. (1987). Production and characterization of a pulluanase and a protease from Thermaactinomyces thalpophilus. Ph.D thesis. Department of Microbiology, Iniversity of Nigeria, Asukka, Nigeria.

[49] Okolo, B.N., Ezeogu, L.I. and Mba, C.N. (1995). Production of raw starch digesting amylase by Aspergillus niger and Bacillus alvei grown on native starch sources. Journal of Science Food and Agriculture, 69: 109-115.

[50] Oluwole, O.B., Joaguim, A.A., Olatunji, A.U., Ozumba, A.U. and Odunfa, S.A. (1999). Assessment of the pasting and organoceptic qualities of cocoyam flour from selected Xanthomonas species. Proceedings of $23^{\text {rd }}$ annual conference of NIFST.

[51] Omemu, A.M., Akpan, I., Bankole, M.O. and Teniola, O.D. (2005). Hydrolysis of raw tuber starches by amylase of Aspergillus niger AM07 isolated from the soil. African Journal of Biotechnology, 4(1): 19-25.

[52] Pandey, A., Soccol, C.R. and Mitchell, W. (2000). New development in solid state fermentation: I-Bioprocess and products. Process Biochemistry 35: 1153-1169.

[53] Pelechova, J., Seifert, B. and Smekal, F.(1983). Biosynthesis of L-lysine from paper hydrolyzate with Corynebacterium glutamicum , Kvasny prumi, 29:279-282.

[54] Peterkofsky, B. and Gilvarg, C. (1961). N-Succinyl-Ldiaminopimelic glutamic transaminase. Journal of Biological Chemistry, 236:1432-1435.

[55] Pfefferle, W., Mockel, B., Bathe, B. and Marx, A. (2003). Biotechnological manufacture of lysine. Advances in Biochemical Engineering and Biotechnology, 79: 59115.

[56] Pham, E.B., Galvez, C.F. and Padolina, W.G. (1992). Methionine fermentation by batch fermentation from various carbohydrates. ASEAN food Journal, 7: 34-7.

[57] Pham, E.B., Billanveva, N.D. and Barril, E.R. (1989). Lysine production using homoserine auxotroph of Corynebacterium glutamicum and sugar cane juice enriched with coconut water. Aristt Biotechnology Conference, pp574-77. 
International Journal of Trend in Scientific Research and Development (IJTSRD) @ www.ijtsrd.com eISSN: 2456-6470

[58] Reed, G. (1982). Prescotts and Dunn's Industrial microbiology. 4th edition, AVI Publishing Co., Inc. Westport, USA.

[59] Roy, D.K. and Chatterjee, S.P. (1989). Journal of Folia Microbiologica, 34(1): 11-24.

[60] Shah, A.H. and Hameed, A. (2004). Nutritional and mutational aspects of indigenous lysine production by Corynebacterium glutamicum: comprehensive studies on shake flask fermentation-1. Journal of Chemical Society of Pakistan, 26(4): 416-428.

[61] Shah, A.H., Hameed, A. and Guj Madid, K. (2002). Improved microbial production of lysine by developing a new Auxotrophic mutant of Corneybacterium glutamicum. Pakistan Journal of Biological Sciences, 5(1): 80-83.

[62] Shih, I.L. and M.H. Shen. 2006. Optimization of cell growth and poly (L-lysine) production in batch and fedbatch cultures by Streptomyces albulus IFO 14147. Process Biochem., 41: 1644-1649.

[63] Smekal, F., Adanova, N.I., Leonova, T.V. and Zalceva, Z.M. (1983). Biosynthesis of L-lysine with the strain of corynebacterium glutamicum 10-20/60 using nonstandard source of carbon. Kyasny prumi, 29: 208-211.

[64] Smekal, F., Barta, M., Bulant, V. and Ulbert, S. (1984). Biosynthesis of L-lysine with phosophocarpus flour as nitrogen source. Kvasny prumi, 30:133-136
[65] Smekal, F., Bulant, V. kindlova, E. Mazalova, M. and Ulbert, S: (1982). Production of L-lysine using nonstandard nitrogen sources. Kvasny prumi, 28: 39-40.

[66] Stilling, B.R., Sidwell, V.D. and Hammerle, O.A.(1971).Nutritive quality of wheat flour and Bread supplement with either fish protein concentrate or lysine.Cereal Chemistry, 48: 292-302

[67] Taniguchi, H., Odashima,F., Igarashi.,M. Maruyama,Y. and Nkamura, M.(1982).Characterization of a potato starch digesting bacterium and its production of amylase. Agricultural and Biological Chemistry, 46: 2107-2115

[68] Tosaka, O., Hirakawo, H. and Takinami, K. (1979a). Effect of biotin level on lysine formation in Brevibacterium lactofermentum. Agricultural and Biological Chemistry, 43: 491-5.

[69] Umerie, S.C., Ekwealor, I.A. and Nwagbo, I.O. (2000). Lysine production of Bacillus laterosporus from various carbohydrates and seed meals. Bioresource Technology 75: 249-252.

[70] Wang, J.S., Yung, C.K., Chen, W.L. and Liu, Y.T. (1991). Optimization of culture conditions for L-lysine fermentation by Brevibacterium species Report of Taiwan Sugar Research Institute, 134: 37-48. 